\title{
Redesain Terminal Tirtonadi Dengan Pendekatan Green Terminal Di SURAKARTA
}

\author{
Nur Aini Prisamsiwi, B. Heru Santosa, Leny Pramesti \\ Program Studi Arsitektur \\ Jurusan Arsitektur Fakultas Teknik \\ Universitas Sebelas Maret Surakarta \\ Email : aini.prisamsiwi@gmail.com
}

\begin{abstract}
Transportation is activity of people and goods in moving from one place to another place. Good transportation must be supported by good infrastructures. Transportation infrastructures consist of road, bus stop, bus terminal, rail road, train station, and airport. Bus terminal is one infrastructure which had by every city in Indonesia. Redesigning Tirtonadi Bus Terminal Surakarta is built upon the existing condition of Tirtonadi Bus Terminal in 2013 and the final result of Tirtonadi Bus Terminal development that is not appropriate with Green Terminal concept chosen by the management and the Local Government of Surakarta. This redesign is aimed to obtain appropriate Green Terminal design to change the dirty and polluting image of the bus terminal. The main problem of this design is how to redesign Tirtonadi Bus Station Surakarta by applying Green Terminal Principles. The approach used in this deisgn is Green Terminal principles, they are: ecofriendly builing, eficiency of energy, air quality, water conservation, security, and renewable natural recources management. The result of redesign is Tirtonadi Bus Terminal Surakarta with appropriate Green Terminal concept that the station can be more safe and convenient for the visitors and the building can maintain harmony between architecture and surrounding environment.
\end{abstract}

Keywords: Architecture, Transportation, Redesigning, Bus Terminal, Green Terminal

\section{PENDAHUluAN}

Transportasi merupakan proses kegiatan memindahkan barang dan orang dari satu tempat ke tempat yang lain. Transportasi adalah sarana untuk mencapai tujuan guna menanggulangi kesenjangan jarak dan waktu (Morlok, 1988).

Di Indonesia, sistem transportasi diatur dalam Sistem Transportasi Nasional atau Sistranas yang terdiri dari transportasi jalan, kereta api, sungai, danau, dan penyeberangan yang membentuk sebuah jaringan sehingga transportasi yang efektif dan efisien.

Setiap kota atau kabupaten di Indonesia pada umumnya memiliki terminal sebagai sarana penghubung dalam kota, antarkota, maupun antarnegara dengan tipe terminal yang sesuai dengan cakupan area yang dilayani.

Piala Wahana Tata Nugraha yang didapatkan oleh Kota Surakarta pada tahun 2010 menjadi acuan Kota Surakarta untuk menerapkan Sustainable Transport System. Hal tersebut diwujudkan dengan adanya pelebaran dan pengembangan Terminal Tirtonadi Surakarta dengan konsep Green Terminal yang diwujudkan dengan alokasi ruang terbuka hijau sebesar $10 \%$ dari luas terminal.

Terminal Tirtonadi Surakarta merupakan terminal Tipe A yang melayani angkutan antarkota antarprovinsi (AKAP), angkutan antarkota dalam provinsi (AKDP), angkutan dalam kota dan angkutan pedesaan. Terminal Tirtonadi Surakarta melayani penumpang selama 24 jam karena Terminal Tirtonadi merupakan terminal yang dilintasi oleh banyak trayek yang menghubungkan satu kota dengan kota lain di Pulau Jawa.

Konsep Green Terminal memiliki beberapa aspek penting, antara lain: bangunan yang seirama dengan lingkungan, efisiensi energi, kualitas udara, keamanan, penggunaan dan 
pengelolaan sumber daya alam terbarukan (Pedric, 2006)

Penelitian awal yang telah dilakukan pada tiga tahap pembangunan terminal (2010-2013) menunjukkan bahwa terdapat beberapa aspek yang tidak sesuai dengan konsep Green Terminal, antara lain:

- lampu dinyalakan pada siang hari karena ruangan yang tidak mendapatkan pencahayaan alami yang cukup;

- sistem pendingin udara diatur hingga $18^{\circ} \mathrm{C}$;

- desain emplasemen dan parkir kendaraan yang berada di dalam ruangan mengakibatkan gas buang kendaraan tidak dapat keluar ruangan;

- desain emplasemen yang paralel dengan ruang tunggu mengakibatkan calon penumpang menyeberangi jalur bus untuk menuju emplasemen.

Berdasarkan poin-poin di atas maka permasalahannya adalah "Bagaimana Konsep Perencanaan dan Perancangan Redesain Terminal Tirtonadi dengan Pendekatan Green Terminal"

\section{METODE}

Metode yang dilakukan untuk mencapai tujuan dan sasaran adalah metode pemrograman arsitektur yang terdiri dari gagasan awal, penelusuran dan rumusan permasalahan, pencarian data (referensi, preseden, dan teoritik), pengolahan data dan informasi, dan konsep perancangan (building performance concept) dan konsep perancangan (programming and design criteria) dan transformasi arsitektur.

\subsection{Temuan dan Penelusuran Masalah Problem Finding)}

Penelusuran masalah dimulai dengan survey awal yang dilakukan pada area pengembangan Terminal Tirtonadi Surakarta yang didesain sebagai green terminal. Permasalahan yang banyak muncul adalah bangunan yang kurang memenuhi konsep green terutama pada masalah pencahayaan dan penghawaan. Di samping itu, sistem sirkulasi dari luar maupun dalam terminal harus dapat memberikan keamanan dan kenyamanan bagi penggunanya.

\subsection{Temuan Konsep Perencanaan dan Perancangan}

Pemahaman tentang Redesain Terminal Tirtonadi Surakarta dikembangkan dengan adanya kajian pustaka: teoritik, preseden, dan pengetahuan empirik.

\subsection{Pendekatan dan Temuan Konsep Perencanaan}

Perumusan konsep perancangan dilakukan dengan metode induktif, yaitu pendekatan berdasarkan pengetahuan empirik mengenai Redesain Terminal Tirtonadi Surakarta dengan Pendekatan Green Terminal dan metode deduktif, yaitu pendekatan berdasarkan teori yang membantu mengarahkan pembahasan sesuai dengan perencanaan yang diinginkan. Cara yang digunakan adalah:

\section{Analisis}

Suatu sistem bangunan merupakan terdiri dari beberapa komponen yang diprogramkan. Uraian dan kajian dari data dan informasi digunakan sebagai data yang relevan. Analisis data dilakukan dengan metode analisis deskriptif melalui uraian data serta informasi yang disertai gambar. Tahap analisis terbagi menjadi:

a. Program fungsional untuk mengidentifikasi pengguna

Terminal Tirtonadi Surakarta dengan pendekatan green terminal yaitu pengguna, kegiatan pengguna, alur kegiatan, dan lain-lain.

b. Program performansi untuk menentukan skema kebutuhan pengguna seperti kebutuhan ruang, persyaratan ruang, program ruang, dan lain-lain.

c. Analisis arsitektural merupakan tahap penggabungan hasil identifikasi program fungsional dan performansi. Proses ini dilakukan dengan analisis pengolahan tapak, massa, citra bangunan, tampilan, peruangan, utilitas, dan struktur bangunan. 


\section{Sintesis}

Tahap ini merupakan penggabungan referensi yang berupa teori maupun preseden dan hasil analisis fakta di lapangan sehingga didapatkan kesimpulan untuk mendapatkan konsep perancangan yang sesuai yang nantinya ditransformasikan ke bentuk ungkapan fisik yang dikehendaki sesuai dengan program fungsional, performansi, dan arsitektural.

\section{ANALISIS}

\subsection{Analisis Peruangan}

Analisis kebutuhan ruang bertujuan untuk mengetahui jenis-jenis ruangan yang dibutuhkan oleh terminal. Ruanganruangan ini diperoleh dari pelaku dan kegiatan manusia maupun kendaraan di dalam terminal (lihat Tabel 1).

Tabel 1. Kebutuhan Ruang

\begin{tabular}{lll}
\hline Pelaku & Kegiatan & Peruangan \\
\hline Kendaraan & $\begin{array}{l}\text { Penurunan } \\
\text { dan penaikkan } \\
\text { penumpang }\end{array}$ & Emplasemen \\
& Parkir & Area Parkir \\
& Perbaikan & Bengkel \\
& Pembersihan & Area Cuci \\
Calon & Datang & Hall \\
Penumpang, & Penurunan & Emplasemen \\
Penumpang, & dan penaikkan & \\
Pengantar, & penumpang & \\
Penjemput & Membeli tiket & Penjualan tiket \\
& Menunggu & Ruang Tunggu \\
& kendaraan & Parkir \\
& Menitipkan & kendaraan \\
& kendaraan & pribadi \\
pribadi & \\
& Ibadah & Masjid \\
& Makan \& & Kafetaria \\
minum & \\
& MCK & Toilet \\
& & \\
Pengelola & Datang & Hall \\
& Bekerja & Kantor UPTD \\
& Ibadah & Masjid \\
& Makan \& & Kafetaria \\
minum & \\
& MCK & Toilet \\
Delaku & Datang & Hall \\
Bekerja & Kios \\
\hline & & \\
& & \\
& & \\
& & \\
& & \\
& & \\
& & \\
& &
\end{tabular}

\begin{tabular}{lll}
\hline & Ibadah & Masjid \\
& Makan \& \\
minum & Kafetaria \\
& MCK & Toilet \\
Kru & Istirahat & Mess Kru \\
Angkutan & Ibadah & Masjid \\
& Makan \& & Kafetaria \\
& minum & \\
& MCK & Toilet \\
& & \\
\hline
\end{tabular}

\subsection{Analisis Jalur Kendaraan}

\subsubsection{Jalur Kedatangan}

Jalur kedatangan direncanakan sebanyak 6 jalur yang terbagi menjadi:

- 2 jalur mikrobus (bus kota, bus pedesaan)

- 4 jalur bus AKDP dan AKAP

\subsubsection{Jalur Keberangkatan}

a. Keberangkatan Barat

- Semarang (Terminal Terboyo)

- Semarang (Terminal Mangkang)

- Yogyakarta (Ekonomi)

- Yogyakarta - Magelang Temanggung

- Bus malam (Jakarta, Bandung, Sumatera)

- Angkutan Pedesaan

- BST dan Damri Bandara

b. Keberangkatan Timur

- Wonogiri-Pacitan

- Purwodadi-Blora

- Karanganyar-Tawangmangu

- Sragen

- Surabaya (3 jalur)

- Bus Malam (Malang, Denpasar, Mataram)

- Lintas/Pedesaan

\subsection{Analisis Tapak}

Tapak berada di lokasi Terminal Tirtonadi Surakarta saat ini yaitu di Jalan Ahmad Yani, Banjarsari, Surakarta yang memiliki luas 4,9Ha. Luas tapak ini kurang dari standar yang diberikan oleh Kementerian Perhubungan yaitu seluas $5 \mathrm{Ha}$, namun pemerintah Surakarta melalui Dinas Perhubungan Surakarta tidak merelokasi 
terminal karena lokasi saat ini berada di tengah kota dan dapat mengakomodasi dari berbagai arah. Tapak ini berada pada jalan utama yang memiliki lebar \pm 16 meter yang terdiri dari empat lajur yang memuat dua arah kendaraan.

\subsection{Analisis Klimatologi}

Dikarenakan arah angin masih dapat dibelokkan sementara sinar matahari tidak, maka orientasi bangunan lebih diarahkan untuk mengantisipasi sinar matahari (Lippsmeier, 1994).

Angin di negara tropis termasuk Indonesia rata-rata berhembus dari tenggara ke barat laut dan sebaliknya sehingga bangunan yang dapat merespon angin dengan baik adalah bangunan yang memanjang dari arah barat daya ke timur laut.

Mengacu pada pendapat Karyono (2010), "Pengurangan radiasi matahari pada bangunan dapat dilakukan dengan menciptakan 'pembayangan' oleh bangunan lain di sekitarnya, atau dengan pembayangan pohon besar di sekitar bangunan. Jika perolehan panas matahari dapat diminimalkan, maka suhu udara di dalam bangunan akan rendah".

Berdasarkan analisis angin dan matahari, orientasi bangunan menghadap utara. Selain untuk mendapatkan pencahayaan alami, bangunan juga masih mendapatkan penghawaan alami yang baik (lihat Gambar 1).

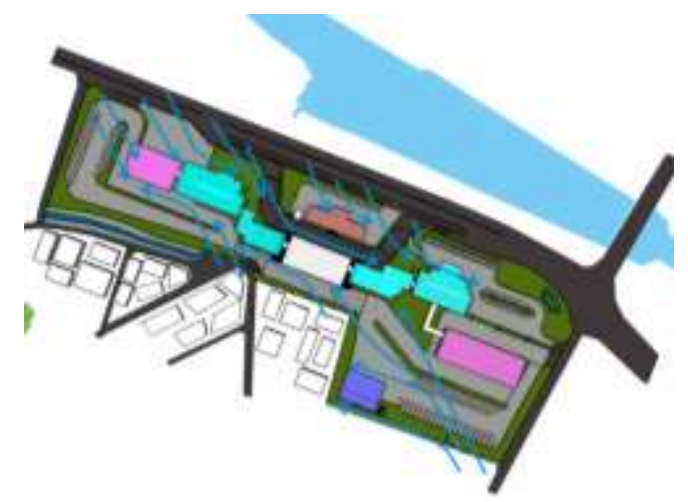

Gambar 1. Pergerakan Angin pada Tapak

\subsection{Analisis Pencapaian}

Analisis pencapaian bertujuan untuk menentukan main entrance (ME). Pencapaian bagi seluruh kendaraan mengikuti kondisi eksisting karena kebijakan tersebut telah melalui serangkaian uji kelayakan.

Main entrance (ME) untuk seluruh kendaraan baik bus, kendaraan pribadi mauupun travel berada pada sisi utara atau sisi Jalan Ahmad Yani.

Pintu ke luar bus sesuai dengan eksisting, yaitu terbagi menjadi dua, pintu bus arah barat dan arah timur sedangkan kendaraan pribadi, pintu ke luar basement diarahkan menuju belakang terminal untuk menghindari kepadatan di Jalan Ahmad Yani (lihat Gambar 2).

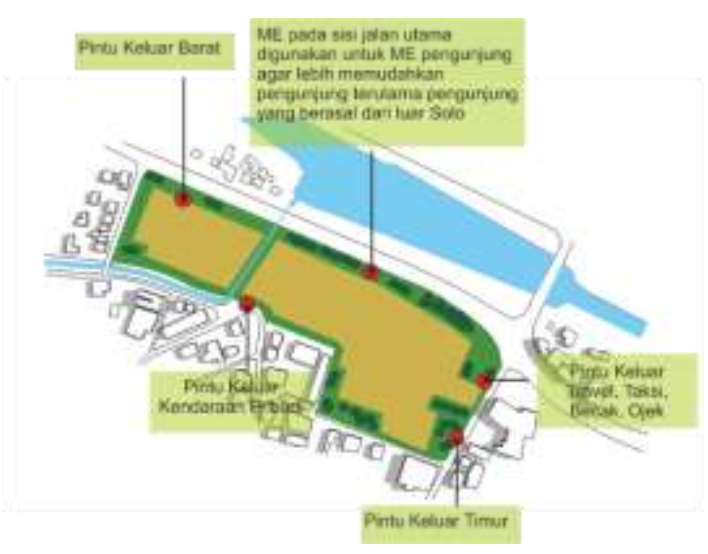

Gambar 2. Analisis Pencapaian

Sisi utara atau Jalan Ahmad Yani dibuat jalur khusus yang sejenis dengan jalur lambat bagi kendaraan yang akan masuk ke terminal sehingga tidak mengakibatkan kemacetan ketika terjadi antrian kendaraan yang akan masuk ke terminal (lihat Gambar 3). 


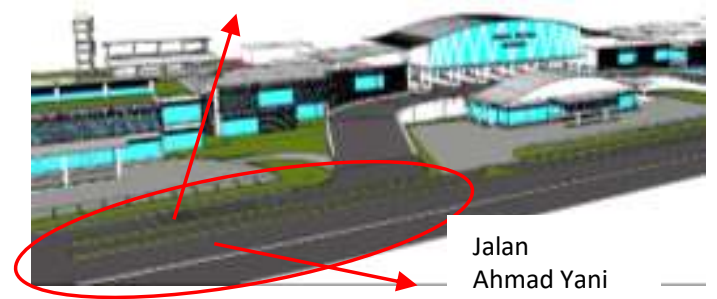

Gambar 3. Jalur Lambat Menuju ME

\subsection{Analisis Pemintakatan (Zoning)}

Pemintakatan (zoning) bertujuan untuk mengelompokkan ruang berdasarkan sifat kegiatan dan tuntutan ruang (lihat Tabel 2).

Tabel 2. Pemintakatan

\begin{tabular}{|c|c|c|}
\hline $\begin{array}{l}\text { Kelompok } \\
\text { Ruang }\end{array}$ & Ruang & Tuntutan \\
\hline Utama & $\begin{array}{l}\text { - Semua } \\
\text { ruang } \\
\text { kegiatan } \\
\text { utama: } \\
\text { Ruang } \\
\text { tunggu, area } \\
\text { kedatangan, } \\
\text { area } \\
\text { keberangkat } \\
\text { an, hall, dll } \\
\text { - Ruang } \\
\text { informasi, } \\
\text { agen tiket, } \\
\text { agen travel }\end{array}$ & $\begin{array}{l}\text { Mudah } \\
\text { dijangkau } \\
\text { - } \text { Dekat dengan } \\
\text { pencapaian } \\
\text { utama (ME) } \\
\text { - Mendapat } \\
\text { pencahayaan dan } \\
\text { penghawaan } \\
\text { alami yang baik }\end{array}$ \\
\hline \multirow[t]{2}{*}{ Pengelola } & Kantor UPTD & $\begin{array}{l}\text { - Dekat dengan SE } \\
\text { - Dekat dengan } \\
\text { area kelompok } \\
\text { utama } \\
\text { - Mendapatkan } \\
\text { pencahayaan dan } \\
\text { penghawaan } \\
\text { alami }\end{array}$ \\
\hline & $\begin{array}{l}\text { - Ruang/Pos } \\
\text { Pengawas } \\
\text { - Pos } \\
\text { penjagaan } \\
\text { - Pos TPR }\end{array}$ & $\begin{array}{l}\text { - Publik dapat } \\
\text { menjangkau } \\
\text { dengan } \\
\text { persyaratan } \\
\text { tertentu } \\
\text { - Menuntut } \\
\text { pencahayaan dan } \\
\text { penghawaan } \\
\text { alami yang baik }\end{array}$ \\
\hline $\begin{array}{l}\text { Penunjang } \\
\text { Penumpang }\end{array}$ & $\begin{array}{l}\text { - Puskesmas } \\
\text { Pembantu } \\
\text { - Ruang Ibu } \\
\text { Menyusui } \\
\text { - Mushola/M } \\
\text { asjid }\end{array}$ & $\begin{array}{l}\text { - Dapat dijangkau } \\
\text { dengan mudah } \\
\text { dari area publik } \\
\text { - Mendapatkan } \\
\text { pencahayaan dan } \\
\text { penghawaan } \\
\text { yang baik }\end{array}$ \\
\hline
\end{tabular}

\begin{tabular}{lll}
\hline Penunjang & $\bullet$ Parkir bus & $\bullet$ Mudah \\
bus dan kru & - Bengkel & dijangkau \\
& • Ruang cuci & dengan \\
& - Ruang & persyaratan \\
& istirahat kru & tertentu \\
& & - Mendapatkan \\
& & pencahayaan dan \\
& & penghawaan \\
& & yang cukup \\
Pusat & $\bullet$ Kios & Mudah \\
Pertokoan & $\bullet$ Toilet & dijangkau \\
& & penumpang \\
& & maupun \\
& & pengunjung \\
\hline
\end{tabular}

\subsection{Analisis Sirkulasi}

Analisis sirkulasi berfungsi untuk mengatur sirkulasi pengguna baik di dalam tapak maupun di dalam bangunan. Sirkulasi tapak bertujuan untuk menentukan arah sirkulasi kendaraan untuk masuk maupun ke luar tapak. Sirkulasi yang baik untuk terminal adalah tidak bercampurnya sirkulasi untuk manusia dan kendaraan. Selain itu, untuk keamanan, crossing kendaraan harus diminimalkan.

\subsubsection{Sirkulasi Bus}

Sirkulasi bus terjadi pada seluruh area tapak dan terbagi menjadi dua arah yaitu barat dan timur berdasarkan trayek masing-masing (lihat Gambar 4).

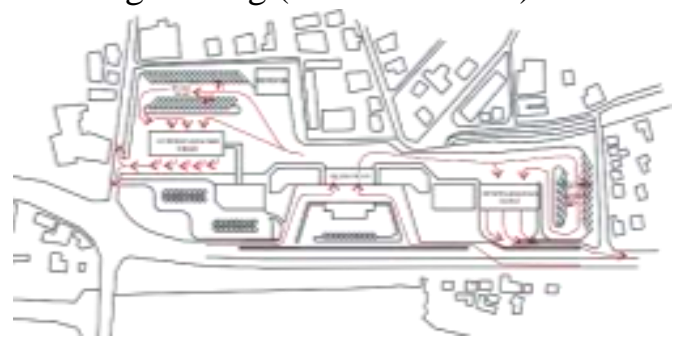

Gambar 4. Sirkulasi Bus

\subsubsection{Sirkulasi Travel dan Taksi}

Sirkulasi travel dan taksi terjadi pada tapak bagian timur. Bagian ini direncanakan hanya untuk angkutan umum non bus (lihat Gambar 5). 


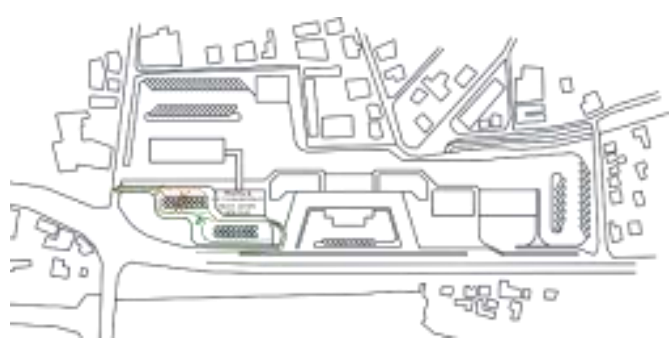

Gambar 5. Sirkulasi Travel dan Taksi

\subsubsection{Sirkulasi Kendaraan Pribadi}

Sirkulasi kendaraan pribadi direncanakan pada bagian tengah tapak. Pintu masuk berada pada sisi jalan utama dan keluar melalui jalan lingkungan di belakang tapak. Kendaraan pribadi yang akan parkir maupun tidak akan melewati basement agar tidak terjadi crossing dengan bus yang melintas (lihat Gambar 6).

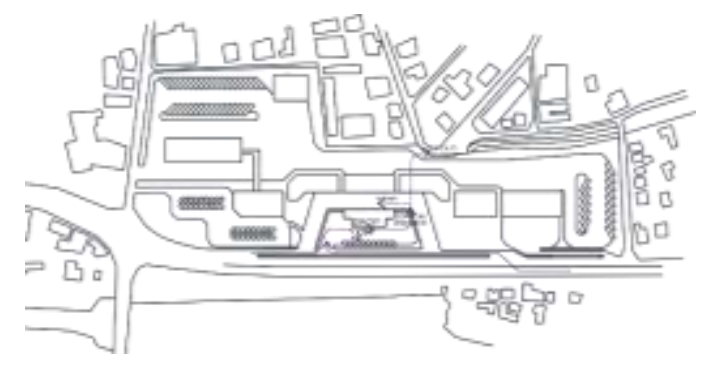

Gambar 6. Sirkulasi Kendaraan Pribadi

\subsection{Analisis Aspek Pengendali Lingkungan}

Analisis aspek pengendali lingkungan adalah analisis terhadap selubung bangunan yang sesuai dengan konsep perencanaannya.

1. Pencahayaan Alami

Analisis sistem pencahayaan bertujuan untuk memperoleh sistem pencahayaan yang sesuai bagi bangunan yang ramah lingkungan.

Pencahayaan alami pada bangunan direncanakan menggunakan dinding kaca dan sistem pencahayaan atap (lihat Gambar 7).

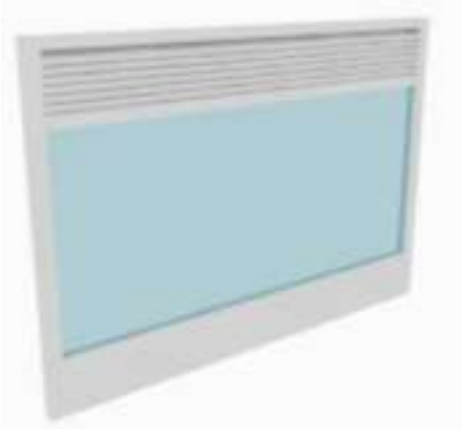

Gambar 7. Rencana Dinding Kaca

2. Pencahayaan Buatan

Pencahayaan buatan akan digunakan pada malam hari atau kondisi cuaca mendung/hujan.

Jenis lampu yang akan digunakan untuk bangunan yang direncanakan adalah lampu LED. Lampu LED memiliki kelebihan umur yang panjang dan wattage yang kecil pada lampu menghasilkan cahaya yang cukup besar sehingga dapat mengurangi penggunaan energi untuk lampu, bahkan wattage lampu LED hanya 1/5 dari lampu pijar.

3. Penghawaan

Analisis penghawaan bertujuan untuk mengendalikan kondisi udara pada tapak.

Bangunan direncanakan menggunakan $\mathrm{AC}$ pada ruang-ruang tertentu seperti ruang pengelola, klinik, dan ruang ibu menyusui sedangkan ruang-ruang lain menggunakan sistem cross ventilation.

Beberapa bagian atap bangunan dilengkapi dengan green roof maupun bukaan udara pada skylight sehingga dapat menurunkan suhu di dalam ruang.

\subsection{Analisis Lansekap}

Analisis lansekap berfungsi untuk menambah estetika, memaksimalkan fungsi ruang terbuka hijau yang ada pada tapak, dan memaksimalkan dan mengarahkan potensi alam (angin dan matahari) pada tapak. 
Menurut Karyono (2005), Salah satu penyebab ketidaknyamanan termis bangunan adalah tingginya suhu udara luar. Rancangan ruang luar dan ruang terbuka kota (taman, jalan dan lainnya) perlu vegetasi yang memadai baik dari segi jumlah maupun penempatan. Vegetasi penyerap $\mathrm{CO}_{2}$ dan memberikan peneduh, turut membantu menyerap radiasi panas matahari dalam jumlah yang besar sehingga menurunkan suhu udara disekitarnya. Hal ini sangat membantu pencapaian kenyamanan termis manusia di dalam maupun di luar bangunan.

Dalam perencanaan redesain Terminal Tirtonadi dengan pendekatan Green Terminal, lansekap berfungsi sebagai berikut:

1. Menciptakan view ke dalam tapak yang menarik

2. Memberi keseimbangan antarruang dengan massa bangunan sehingga terbentuk pola yang harmonis

3. Mengurangi polusi udara yang ditimbulkan oleh kendaraan/bus yang melintas di terminal

4. Menjadi penunjuk arah bagi penggunanya

5. Menjadi pelindung bagi pejalan kaki. Hal ini berguna untuk keamanan dan barrier bagi penggunanya.

Pohon yang digunakan untuk lansekap terdiri dari dua jenis pohon yaitu pohon peneduh dan pohon pengarah. Pohon peneduh berupa kiara payung diletakkan pada area parkir dan batas tapak sedangkan pohon pengarah yang berupa palem diletakkan pada jalur-jalur kendaraan.

Hardscape yang digunakan pada tapak berupa beton pada area penurunan penumpang, penaikkan penumpang, dan area parkir sedangkan paving digunakan pada area lain yang berupa area sirkulasi. Paving dipilih karena dapat menyerap air lebih banyak dibandingkan dengan aspal maupun beton (lihat Gambar 8).

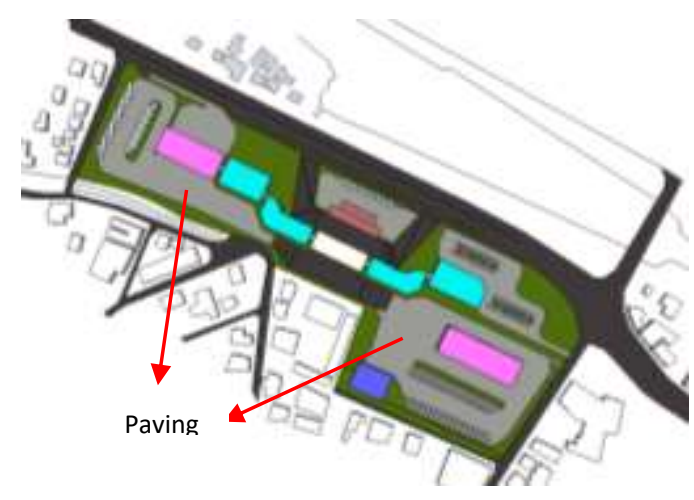

Gambar 8. Penggunaan Paving pada Tapak

\subsection{Analisis Utilitas}

\subsubsection{Sistem Kelistrikan}

Sistem listrik pada bangunan terminal menggunakan listrik yang berasal dari PLN sebagai sumber listrik utama dan genset untuk suplai listrik pengganti pada saat listrik mati.

Photovoltaic juga dipasang pada dua bagian atap bangunan sebagai sumber listrik tambahan. Sumber listrik ini direncanakan digunakan untuk lampu-lampu pada bangunan.

\subsubsection{Sistem Air Kotor dan Pengolahan} Limbah

Analisis ini bertujuan untuk membuat sebuah sistem pengolahan limbah sehingga air buangan dapat digunakan kembali.

Air buangan yang berasal dari floor drain dan air dari dapur yang berupa grey water diolah dengan pengolah limbah yang berada pada tapak. Air yang telah diolah kemudian ditampung pada tangki khusus kemudian dialirkan untuk toilet flush dan sistem pemadam kebakaran (lihat Gambar 9). 


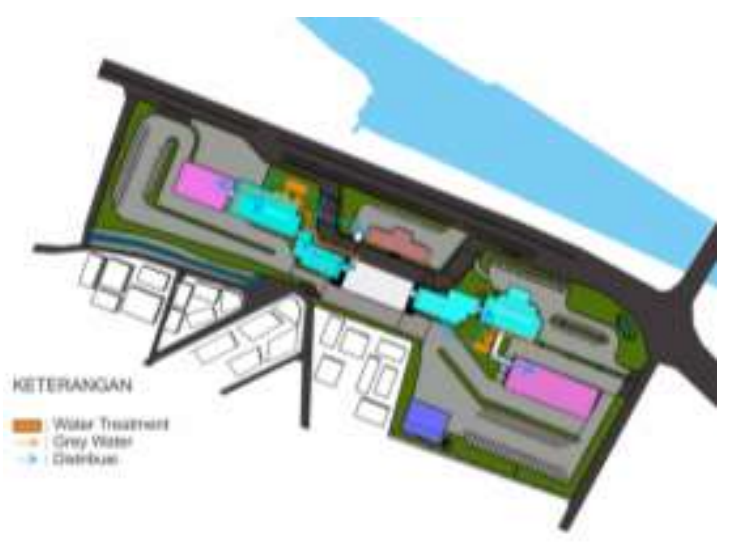

Gambar 9. Titik Pengolahan Air Limbah dan Distribusi

\subsubsection{Sistem Pengolahan Air Hujan}

Curah hujan di Surakarta berkisar antara 100-400 mm pada musim hujan. Angka ini cukup tinggi sehingga air hujan dapat dimanfaatkan agar tidak langsung terbuang ke saluran air kota.

Pengolahan air hujan dilakukan dengan adanya sumur-sumur resapan untuk mengembalikan air ke dalam tanah. Air hujan yang tidak tertampung pada sumur resapan akan disimpan pada tangki air hujan, apabila tangki tidak dapat menampung lagi, air hujan akan dialirkan menuju saluran air kota.

Air hujan yang ditampung pada tangki air hujan akan dimanfaatkan untuk menyiram tanaman dan sumber air tambahan untuk pemadam kebakaran (lihat Gambar 10).

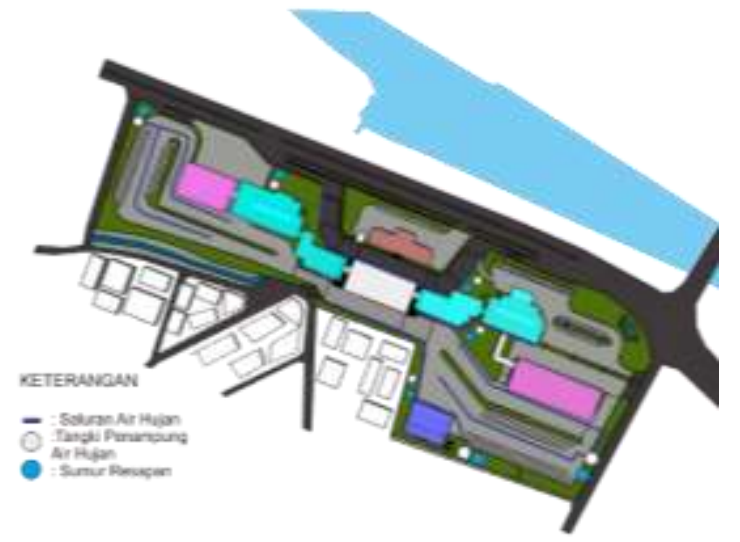

Gambar 10. Titik Sumur Resapan dan Tangki

\section{KESIMPULAN (KONSEP DESAIN)}

Dari hasil analisa serta hasil korelasi dari beberapa data di atas, maka diperoleh hasil berupa:

Nama : Terminal Tirtonadi

Lokasi : Jl. Ahmad Yani

Luas Lahan

$$
\text { : } 49.056 \mathrm{~m}^{2}
$$

Luas Bangunan : 22.881,2 $\mathrm{m}^{2}$

Konsep Green Terminal diterapkan pada tapak dan bangunan, antara lain:

1. Ruang Terbuka Hijau (RTH) sebesar $25 \%$ dari luas lahan untuk memperbaiki kondisi udara di lingkungan terminal (lihat Lampiran $1)$;

2. Penghematan energi dilakukan dengan cara orientasi bangunan menghadap ke utara sehingga mendapat cahaya dan udara yang cukup;

3. Lebar bangunan antara 14-21 meter memungkinkan cahaya dan udara dari luar dapat masuk ke seluruh ruangan;

4. Penggunaan dinding kaca dengan secondary skin untuk mengurangi efek panas yang ditimbulkan oleh cahaya matahari (lihat Gambar 11);

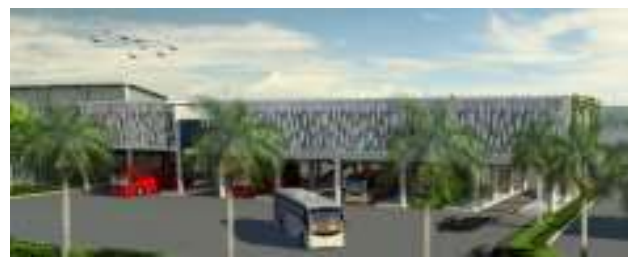

Gambar 11. Secondary Skin

5. Sistem keamanan diterapkan dengan adanya ram yang menghubungkan tiap emplasemen kota tujuan dengan ruang tunggu (lihat Gambar 12);

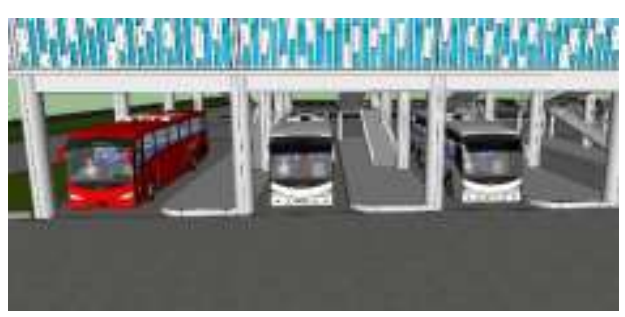

Gambar 12. Emplasemen Kendaraan 
6. Efisiensi air dilakukan dengan pengolahan grey water dan menampung air hujan untuk digunakan sebagai sumber air tambahan;

7. Penggunaan photovoltaic sebagai sumber energi untuk lampu di dalam maupun di luar ruangan;

8. Penggunaan green roof pada atap bangunan untuk menurunkan suhu ruangan di bawahnya (lihat Gambar 13).

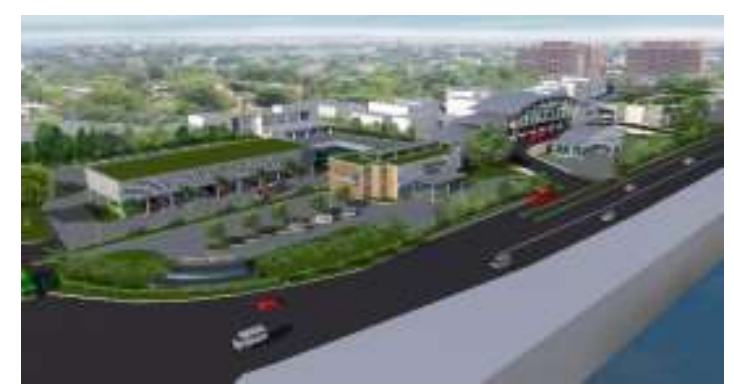

Gambar 13. Green Roof pada Atap Bangunan

\section{REFERENSI}

Karyono, Tri Harso. 2005. Fungsi Ruang Hijau Kota Ditinjau dari Aspek Keindahan, Kenyamanan, Kesehatan dan Pengehematan Energi.

Karyono, Tri Harso. 2010. Green Architecture: Pengantar Pemahaman Arsitektur Hijau di Indonesia. Rajawali Pers.

Lippsmeier, Georg. 1999. Bangunan Tropis. Jakarta: Erlangga.

Morlok, Edward K. 1988. Pengantar Teknik dan Perencanaan Transportasi. Jakarta: Erlangga.

Pedric, Drew. 2006. Green Terminal Design.

(Presentation) 